\title{
Germination of Seeds of Selected Leguminous Tree Species Moistened with Varying Concentrations of Crude Oil-Contaminated Soil Water Extracts
}

\author{
Ayodele Adelusi Oyedeji1,2,3*, Joshua Kayode², Lynn Besenyei' ${ }^{1}$, Michael Augustine Fullen'1 \\ ${ }^{1}$ Faculty of Science and Engineering, University of Wolverhampton, Wolverhampton, UK \\ ${ }^{2}$ Department of Plant Science, Faculty of Science, Ekiti State University, Ado-Ekiti, Nigeria \\ ${ }^{3}$ Department of Biological Sciences, Niger Delta University, Wilberforce Island, Nigeria \\ Email: *ayodele.oyedeji@yahoo.com
}

Received 18 March 2015; accepted 23 June 2015; published 26 June 2015

Copyright (C) 2015 by authors and Scientific Research Publishing Inc.

This work is licensed under the Creative Commons Attribution International License (CC BY). http://creativecommons.org/licenses/by/4.0/

\section{(c) (7) Open Access}

\section{Abstract}

The study investigates the germination of selected leguminous tree species (LTS) native to the forest ecosystem and oil producing areas of Nigeria. Germination experiments of 250 seeds from each of the selected members of the Fabaceae family: Bauhinia monandra (Kurz), Delonix regia (Boj. ex Hook.) Raf. and Tetrapleura tetraptera (Schum. \& Thonn.) Taubert were conducted in petri dishes double-layered with Whatman No. 1 filter papers for 10 days and moistened with varying concentrations of crude oil contaminated soil water extracts $(0,25,50,75$ and $100 \mathrm{ml})$, with a view to determining the ability of these plants to germinate and establish in soil polluted with crude oil. The mean percentage germination of each tree species was thus determined. All the LTS germinated, but germination was concentration dependent, as percentage germination decreased with increased oil concentrations. Evaluation of the initial growth responses and tolerances of these LTS in oil-polluted soil may provide useful information about the potential of these plant species for phytoremediation.

\section{Keywords}

Germination, Fabaceae, Crude Oil, Pollution, Phytoremediation, Tree Species

\footnotetext{
${ }^{*}$ Corresponding author.
}

How to cite this paper: Oyedeji, A.A., Kayode, J., Besenyei, L. and Fullen, M.A. (2015) Germination of Seeds of Selected Leguminous Tree Species Moistened with Varying Concentrations of Crude Oil-Contaminated Soil Water Extracts. American Journal of Plant Sciences, 6, 1575-1580. http://dx.doi.org/10.4236/ajps.2015.69157 


\section{Introduction}

Crude oil is a vital natural resource of global importance and one of the most prominent commodities on the world market today. It has been an important part of the Nigerian economy since large oil reserves were discovered in the 1950s. It serves as the basis for the production of energy and primary raw material for petro-chemical and allied industries and is the main source of fuel [1]. The great demand and utilization of petroleum products have encouraged its exploration and exploitation in Nigeria and globally and this increase in the demand has brought many attendant problems of environmental pollution, which have often left damaging impacts on ecosystems. Some of the effects include damage to terrestrial and aquatic life, changes in water quality and destruction of the aesthetic value of beaches, loss of soil fertility and agricultural productivity and considerable environmental and health hazards [2].

Soil is an essential natural resource which acts as a central-point for ecosystem dynamics. It offers a good relationship platform for other components that make the distinctive environment. The various components of the environment interact to continuously provide multiple ecosystem services, including food, fuel and fibre, which are required to support organisms living in the environment [3]. Due to the utilization of soil for more needs, goods and services, largely owing to urbanization, industrialization, exploration of natural resources (such as crude oil) and population growth, there is growing land degradation, including landslides, soil erosion, desertification, soil organic matter decline and contamination. Contaminated soils and sites have some level of contaminants present in them and damage ecosystems. The reports of [4] [5] recognized soil contamination as one of the major threats to soils and the environment. The substances that are capable of offering some degree of contamination to the soil include the spillage of crude oil, petroleum products, heavy metals, mineral pollutants, dumping of wastes, pesticides and other pollutants [6] [7].

Crude oil spillages into aquatic and terrestrial ecosystems have been extensive and often occur during crude oil drilling, burst pipelines due to high pressure, corrosion or sabotage of pipes, tank overflows, tank loading operation failure, leakages and seepages [1] [8]-[10], which causes poisoning of drinking water and destruction of vegetation. The adverse effects of oil pollution on some food crops have been reported [2] [11] [12]. High oil concentrations in soil cause decreased growth [12]-[14]. The effect of oil spillage on agricultural soil is of great concern and requires solutions. To curb environmental contamination resulting from oil spillage in an environmentally-friendly manner and ensure cost effectiveness, good phytoremediation processes are now practised in many countries, including the USA, UK and Brazil.

Phytoremediation is a form of biological remediation (bioremediation) strategy that involves the use of living plants, often with soil amendments with associated microbes in the root system of plants for the removal, degradation, extraction and detoxification of contaminants (both organic and inorganic) in soils, sludge, sediments, air and groundwater [1] by absorbing, translocating or sequestering organic contaminants and removing them from the soil compartment [15]. The use of plants in remediation of soil and unconfined groundwater is appealing for several reasons:

1. Plants provide a remediation strategy that utilizes solar energy.

2. Vegetation is aesthetically pleasing.

3. Plant samples can be harvested and tested as indicators of the level of remediation.

4. Plants help contain the region of contamination by removing water from soils.

5. Rhizosphere microbial communities are able to biodegrade a wide variety of organic contaminants.

6. Many plants have mechanisms for transporting oxygen to the rhizosphere [16].

However, before effective plant remediation strategies can be developed, an understanding is required of the physical, chemical and biological relationships that determine the fate of each contaminant in the rhizosphere.

Phytoremediation is a non-destructive, cost-effective insitu technology that uses plants and their associated micro-organisms to clean up contaminated soils and is, therefore, appropriate and useful in environmental and ecological research [17]. It has become a practical solution for the remediation of petroleum hydrocarbon polluted sites [10] [18]. Plants that can grow well in crude oil contaminated soil have been described as potentially suitable species for the phytoremediation of crude oil-polluted soil [19]. Before a plant species can grow well in crude oilpolluted soil, plants must be able to germinate well in such soil. The present study is therefore designed to evaluate the germination of selected native leguminous plant species commonly found growing in the forest ecosystem of oil bearing regions of Nigeria, with a view to further determine their initial growth rate, tolerance and effectiveness in remediating crude oil contaminated soils. 


\section{Materials and Methods}

Five medium sized plastic plant pots were filled with top sandy loamy soil from the Research Experimental Farm of Ekiti State University (EKSU), Ado-Ekiti, Nigeria $\left(7^{\circ} 40^{\prime} \mathrm{N} ; 5^{\circ} 15^{\prime} \mathrm{E}\right)$. The plant pots, with a uniform weight of $4000 \mathrm{~g}$ were arranged in the greenhouse. The soil was artificially contaminated with varying amounts $(0,25,50$, 75 and $100 \mathrm{ml}$ ) of crude oil and thoroughly mixed in a large basin. The varying amount of oil in soil represents the treatments. Samples of $200 \mathrm{~g}$ of the polluted soil were measured out from each of treatment (0, 25, 50, 75 and 100 $\mathrm{ml}$ ) with the aid of the DTA Series Electronic Scale FED-3000 and each was displaced in 1000 ml measuring cylinder containing distilled water and left to soak for 72 hours. The aqueous extracts were filtered and the filtrates were collected in $500 \mathrm{ml}$ conical flasks.

Seventy-five sterile petri dishes (Figure 1) were each double layered with Whatman No 1 filter paper and divided into three groups; a group for each plant species. In each group, there were treatments: 0, 25, 50, 75 and 100 $\mathrm{ml}$ water extract and replicated five times. Ten seeds of each plant species (B. monandra, D. regia, T. tetraptera; all of the Fabaceae family) were sown in each Petri-dish and moistened daily at 0700 for 10 days to determine the germination of the seeds of selected plant species. Germination counts were made daily and recorded for 10 days after sowing. Germination in each treatment and its control was calculated and data compared by means of bar charts. Percentage germination was computed, modifying the formula adopted by [2]:

$$
\text { Germination test Percentage }(\mathrm{Gt} \%)=\frac{\text { Number of seedling that emerged } / \text { dish } \times 100}{\text { Total number of seed sown }}
$$

\section{Results}

Figure 2 shows the germination percentage of $D$. regia in crude oil contaminated soil water extracts. Soil treated with 0, 25, 50, 75 and $100 \mathrm{ml}$ crude oil had 100\%, 90\%, 82\%, 78\% and 60\% germination, respectively. Germination percentages of 100, 90, 74, 70 and 58 were achieved in B. monandra moistened with the varying crude oil contaminated water extracts (Figure 3), T. tetraptera had germination percentages of 88\%, 80\%, 72\%, 68\% and $56 \%$ when moistened with $0,25,50,75$ and $100 \mathrm{ml}$ crude oil contaminated soil water extracts, respectively (Figure 4). All the LTS germinated when moistened with crude oil contaminated water extracts, but germination was concentration dependent, as percentage germination decreased with increased oil concentrations. The germination percentage of the selected tree species varied. $D$. regia tended to have better germination than $B$. monandra and T. tetraptera, even at high concentration of crude oil in the soil water extracts (Figure 5) and there was an inverse association between the germination of the plant species and contamination, which was significant at $P<0.05$ using correlation analysis.

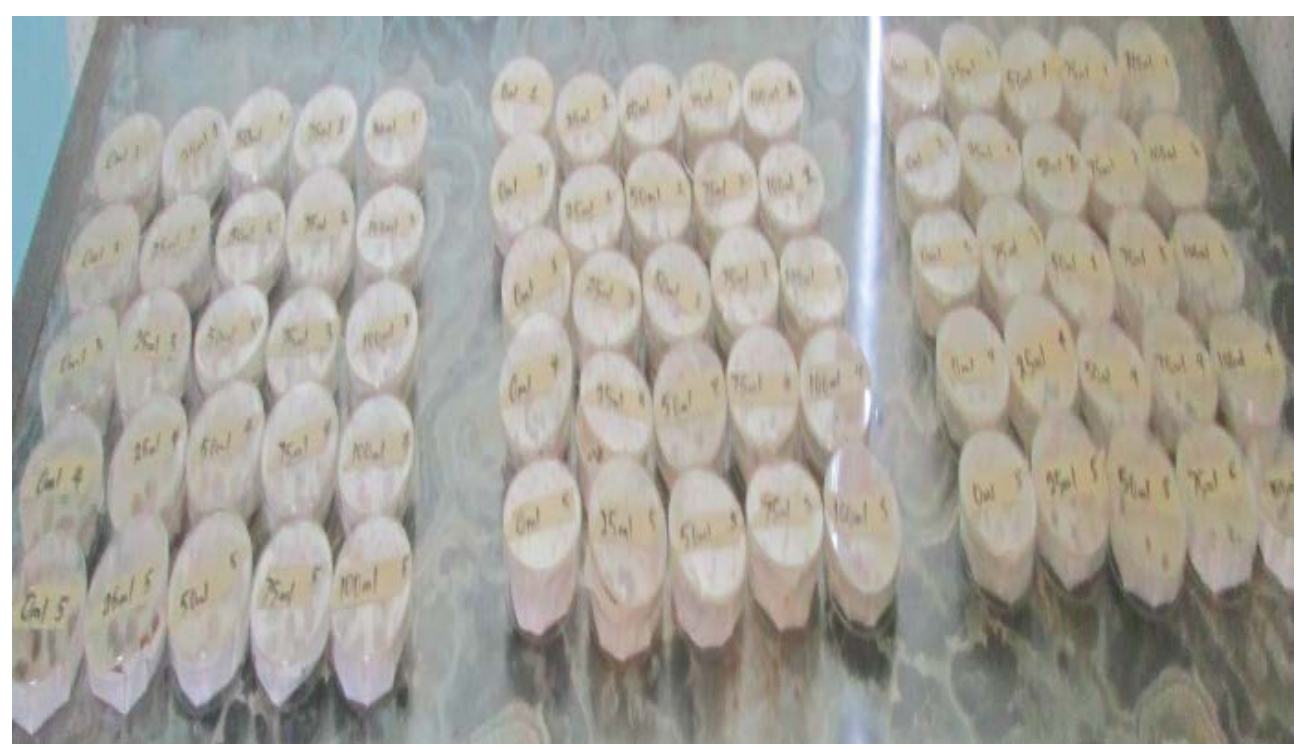

Figure 1. Layout of germination experiment of the selected leguminous tree species. 


\section{A. A. Oyedeji et al.}
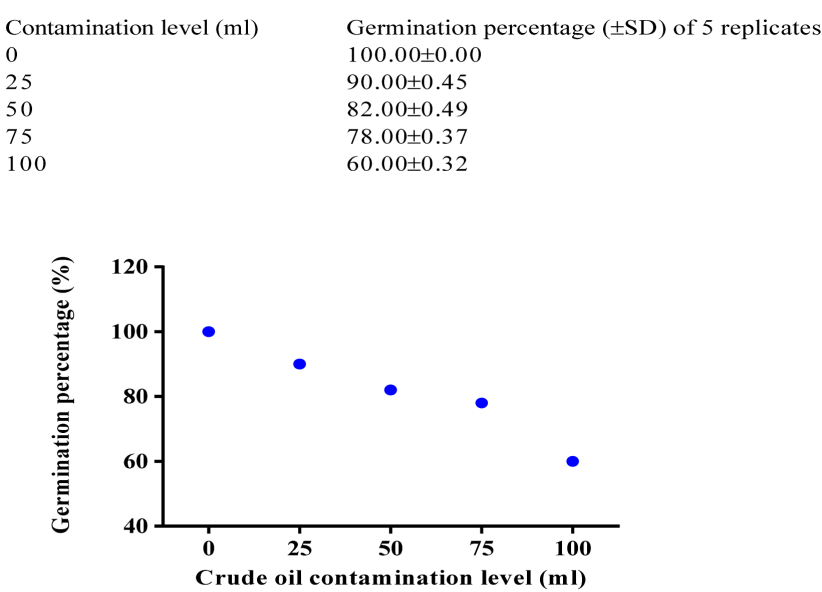

$\mathbf{n}=5 ; \quad \mathrm{N}=\mathbf{2 5} ; \quad \mathbf{r}=\mathbf{- 0 . 9 7 6 ;} \quad \mathrm{P}<0.004^{*} ;{ }^{*}$ Significant at $\mathrm{P}<0.05$

Figure 2. Germination of $D$. regia in crude oil contaminated soil water extracts.
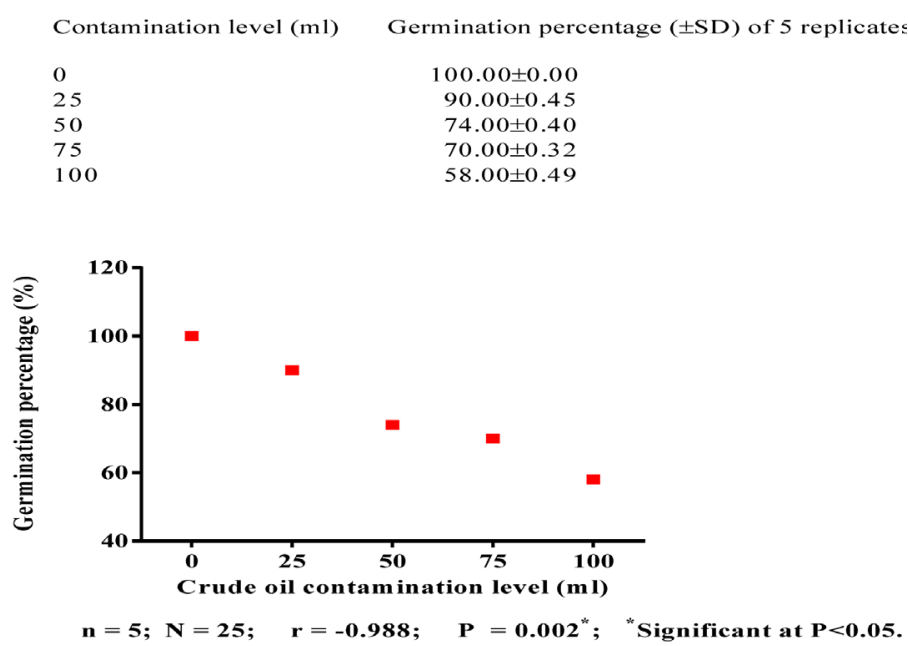

Figure 3. Germination of $B$. monandra in crude oil contaminated soil water extracts.

$\begin{array}{ll}\text { Contamination level } & \text { Germination percentage }( \pm \mathrm{SD}) \text { of } 5 \text { replicates } \\ 0 & 88 \pm 0.374 \\ 25 & 80 \pm 0.316 \\ 50 & 72 \pm 0.374 \\ 75 & 68 \pm 0.200 \\ 100 & 56 \pm 0.510\end{array}$

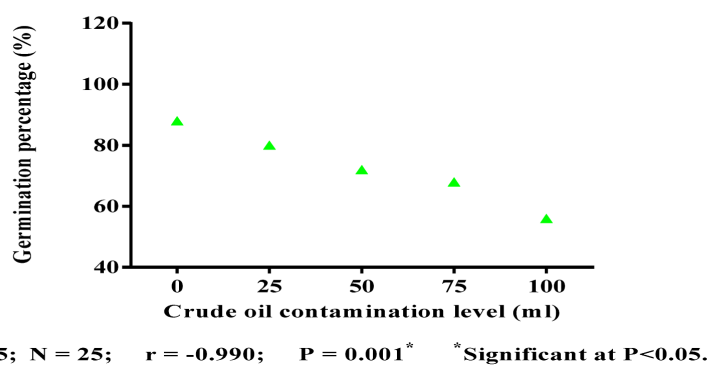

Figure 4. Germination of $T$. tetraptera in crude oil contaminated soil water extracts. 

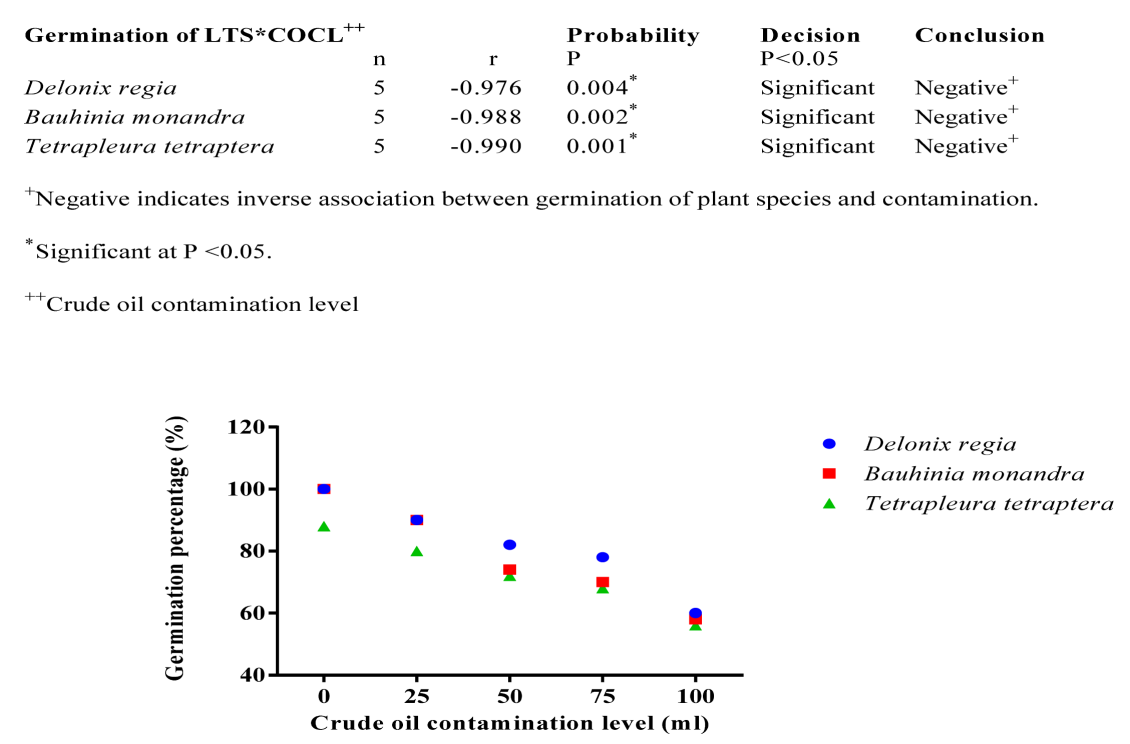

Figure 5. Comparison of percentage germination among selected leguminous tree species moistened with varying concentrations of crude oil contaminated water extracts.

\section{Discussion}

High concentrations of oil in soil usually stunt most plant species growth [12]-[14], but some plants can withstand some oil contamination [7]. The present study revealed the potential of the seeds of B. monandra, D. regia and T. tetraptera to germinate when moistened with crude oil contaminated soil water extracts at different concentrations and this is similar to the report of [19] which affirmed that some plants grow well in oil-contaminated soil and described such plants as potentially suitable species for the phytoremediation of crude oil-polluted soil. Phytoremediation is recommended as a practical solution for the remediation of petroleum hydrocarbon polluted sites [10] [18]. However, before a plant species can grow well in crude oil-polluted soil, such plants must be able to germinate well in such soil.

\section{Conclusions}

B. monandra, D. regia, and T. tetraptera germinated when moistened with crude oil-contaminated soil water extracts of varying concentrations $(25-100 \mathrm{ml})$. This suggests that these species demonstrated promising results as being suitable for use in phytoremediation of crude oil-polluted soils. Further investigations are in progress aimed at the assessment of the phytoremediation potential of these species and fitness of these tree species for re-vegetation of crude oil-contaminated soils in Nigeria.

\section{Acknowledgements}

The authors are grateful to the Petroleum Technology Development Fund, Abuja, Nigeria, for funding this research. The efforts of Technical staff at the Department of Plant Science, EKSU are gratefully acknowledged.

\section{References}

[1] White, P.M., Wolf, D.C., Thoma, G.J. and Reynolds, C.M. (2006) Phytoremediation of Alkylated Polycyclic Aromatic Hydrocarbons in a Crude Oil-Contaminated Soil. Water, Air and Soil Pollution, 169, 207-220. http://dx.doi.org/10.1007/s11270-006-2194-0

[2] Kayode, J. and Oyedeji, A.A. (2012) Early Growth Response of Maize (Zea mays L.) in Spent Lubricating Oil-Polluted Soil. Environtropica Journal, 8, 132-138.

[3] Kassam, A. (2009) Sustainability of Farming in Europe: Is There a Role for Conservation Agriculture? Journal of Farm Management, 13, 11-22.

[4] European Commission (2002) Towards a Thematic Strategy for Soil Protection. Communication from the Commission to the Council, the European Parliament, the Economic and Social Committee and the Committee of the Regions, COM, 
179.

[5] European Commission (2006) Proposal for a Directive of the European Parliament and of the Council Establishing a Framework for the Protection of Soil and Amending Directive 2004/35/EC. Directive COM, 232.

[6] Nwaugo, V., Onyeagba, R. and Nwachukwu, N. (2006) Bacteriological Quality of Cercarial (S. heamatobium) Infested Abandoned Quarry Pit Water. Journal of Engineering Science and Technology, 13, 6697-6706.

[7] Osam, M.U., Wegwu, M.O. and Ayalogu, E.O. (2011) Biochemical and Physicochemical Assessment of the Efficacy of Some Wild-Type Legumes in the Remediation of Crude-Oil Contaminated Soils. Archives of Applied Science Research, 3, 247-256.

[8] Adesida, A.A. (2000) Environmental Geological Investigation of Hydrocarbon Pollution of Soil and Ground Water within the Upper Continental Sequences of the Tertiary Niger Delta. Seminar Presentation, Department of Geology, University of Benin, Benin.

[9] Osuji, L.C. and Onojake, C.M. (2004). Trace Heavy Metals Associated with Crude Oil: A Case Study of Ebocha-8 Oil-Spill-Polluted Site in the Niger Delta, Nigeria. Chemistry and Biodiversity, 1, 1708-1715. http://dx.doi.org/10.1002/cbdv.200490129

[10] Tanee, F. and Kinako, P. (2008) Comparative Studies of Biostimulation and Phytoremediation in the Mitigation of Crude Oil Toxicity in Tropical Soil. Journal of Applied Sciences and Environmental Management, 12, 143-147.

[11] Isirimah, N., Zuofa, K. and Longanathan, P. (1989) Effect of Crude Oil on Maize Performance and Soil Chemical Properties in the Humid Forest Zone of Nigeria. Discovery and Innovation, 1, 95-98.

[12] Kayode, J., Olowoyo, O. and Oyedeji, A. (2009) The Effects of Used Engine Oil Pollution on the Growth and Early Seedling Performance of Vigna uniguiculata and Zea mays L. Research Journal of Soil Biology, 1, 15-19. http://dx.doi.org/10.3923/rjsb.2009.15.19

[13] Amakiri, J. and Onofeghara, F. (1983) Effect of Crude Oil Pollution on the Growth of Zea mays, Abelmoschus esculentus and Capsicum frutescens. Oil and Petrochemical Pollution, 1, 199-205. http://dx.doi.org/10.1016/S0143-7127(83)90182-5

[14] Anoliefo, G. and Okoloko, G. (2000) Comparative Toxicity of Forcados Blend Crude Oil and Its Water-Soluble Fraction on Seedlings of Cucumeropsis manni naudin. Nigerian Journal of Applied Science, 18, 39-49.

[15] Cunningham, S.D., Anderson, T.A., Schwab, A.P. and Hsu, F. (1996) Phytoremediation of Soils Contaminated with Organic Pollutants. Advances in Agronomy, 56, 55-114.

[16] Shimp, J.F., Tracy, J.C., Davis, L.C., Lee, E., Huang, W., Erickson, L.E. and Schnoor, J.L. (1993) Beneficial Effects of Plants in the Remediation of Soil and Groundwater Contaminated with Organic Materials. Critical Reviews in Environmental Science and Technology, 23, 41-77. http://dx.doi.org/10.1080/10643389309388441

[17] Nie, M., Wang, Y., Yu, J., Xiao, M., Jiang, L., Yang, J., Fang, C., Chen, J. and Li, B. (2011) Understanding PlantMicrobe Interactions for Phytoremediation of Petroleum-Polluted Soil. PloS ONE, 6, e1796.

[18] Frick, C., Farrell, R. and Germida, J. (1999) Assessment of Phytoremediation as an in Situ Technique for Cleaning Oil-Contaminated Sites. Petroleum Technology Alliance of Canada (PTAC), Calgary.

[19] Bamidele, J. and Agbogidi, O. (2006) The Effect of Soil Pollution by Crude Oil on Seedling Growth of Machaerium lunatus (L) GFW Meg. Discovery and Innovation, 18, 104-108. 